\title{
Classroom Factors that Influence Self-esteem in Gifted Children : A Case Study in Sri Lanka
}

\author{
Kamani Priyadarshani ${ }^{1}$, Samudra Senarath ${ }^{2}$ \\ ${ }^{1}$ National College of Education, Colombo \\ 2 Department of Educational Psychology Faculty of Education, University of Colombo
}

\section{Article Info \\ Volume 8, Issue 5 \\ Page Number : 242-251}

\section{Publication Issue}

September-October-2021

\section{Article History}

Accepted : 20 Sep 2021

Published : 30 Sep 2021

\section{ABSTRACT}

This study examines how factors in the classroom environment influence gifted children and their self-esteem in Junior Secondary level classes in Sri Lanka, using a sample survey design. One hundred and two male and female gifted students at Junior Secondary level from two geographical provinces were selected using the snowballing sampling method, with the Ravens Standardized Matrix Test and teacher nominations. The Coppersmith's Self Esteem Scale was employed to examine these children's self-esteem and a self-developed screening test was implemented to identify the factors in the classroom environment that influenced them. The results of the study revealed that such gifted children presented significant classroom environment trigger factors, such as teaching-learning issues, neglect by the teachers, unhappiness with their teachers, lack of attention from the teachers, teachers' lack of teaching skills and methods, peer pressure and peer relationships issues. Due to these classroom influences, the children presented psychological difficulties including physical, emotional and behavioral difficulties. Of these, emotional difficulties showed higher scores as compared to other difficulties. When considering self-esteem, forty-seven children presented an overall low score in contrast to both average and higher scores in the sample. There was a significant positive correlation between emotional, behavioral and physical difficulties and self-esteem. Thus, it seemed that the development of professional skills and the need for further teacher training related to special education are vital. It is also important to provide integrated professional counselling services to strengthen the self-esteem and well-being of talented children, in the school system.

Keywords: Classroom Environment, Influences, Gifted Children, Psychological Difficulties and Self-esteem 


\section{INTRODUCTION}

The education system in Sri Lanka provides 13 years of education in four cycles. Children from the ages of 5-10 attend primary school (Grades 1-5) and sit for a scholarship examination at the end of grade 5 . Children aged 11-14 are Junior Secondary (Grades 6-9) while children aged 15-16 are categorized as Senior Secondary (Grades 10-11), who sit for the General Certificate Examination Ordinary Level (GCE O/L) at grade 11. Children aged 17-18 (Grades 12-13) belong to the collegiate or General Certificate Examination GCE Advanced Level (GCE A/L). Of these examinations, the grade 5 scholarship exam is regarded as one of the most competitive, since this exam offers entry to better schools with better facilities and a grant of a cash award to those achieving the highest marks. Students who pass this exam are entitled to enroll in popular schools and gifted children are often included in this number. As a result, children from very remote areas have the opportunity to attend urban, popular schools where they live in hostel accommodation, away from home. Owing to these circumstances, the children's psychological needs may not be fulfilled as they live far from the love, care and protection of their parents. After the grade 5 examination, all school children are enrolled at Junior Secondary level, beginning from grade six and gifted children too, adapt to the typical school environment of the Sri Lankan education system. As affirmed in the Salamanca statement, gifted children also belong to the category of Special Educational Needs Children (SEN) as they possess an above average Intelligence Quotient (IQ). Although some countries have established separate schools for gifted children, there are no such separate schools in Sri Lanka for gifted children who therefore must function in typical classroom settings. Gifted children face different challenges within the typical classroom environment and these may lead to various psychological, social and behavioral problems. Kourkouta, Ilitadis, and Monios, (2015), Fallon,
Danielle, and Emina, (2020); Blaas (2014); Lee, Olszewski, Makel and Putallaz (2015) noted that gifted children studying in typical classrooms encountered many difficulties such as anxiety, stress, sleeping problems, social isolation and emotional difficulties etc. According to Mustika, and Harini, (2017) self-esteem and classroom situations play an important role in one's psycho-social development. Kroesbergen et al. (2016); Pilarinos and Solomon (2017) ; Crone and Dahl (2012) showed that gifted children experienced lower self-esteem due to classroom issues-one-third to one-half of gifted children suffer from poor self-esteem, particularly in the early stages of adolescence. In the Sri Lankan context, all students are enrolled in typical classrooms where intelligence quotient levels might vary in a range of 70-130, while some are over 130 . The teaching-learning process has been a very difficult task for both teachers and students. Since the Sri Lankan education system is highly exam-oriented, parents, teachers, principals and education officers play a major role in preparing children for examinations, often pressurizing them towards better performances. The education system also appears to be designed to reward high-mark scores and tends to neglect actual learning and the nurturing of citizens with well-balanced personalities. As a result, due to this prevailing culture, many students suffer tension and stress. Psychological and social issues are common among gifted adolescents in schools. Many teachers and parents focus on high academic achievements rather than on the development of balanced citizens. There are many comprehensive empirical studies presented by international researchers in this area, though a gap exists in modern-day Sri Lankan society. Thus, the research problem of this study was to determine the classroom environment factors that influence gifted children and if there is a relationship between self-esteem and psychological difficulties. 


\section{Aim and Objectives of the Study}

The main objective of this study is to identify the nature of the trigger factors in a classroom environment that cause psychological difficulties and influence the self-esteem of gifted children. Specifically, the purpose of this study is to:

To identify how gifted junior secondary students are Identify the psychological difficulties that gifted students encounter within the typical classroom environment.

Examine the relationship between psychological difficulties including emotional, physical and behavioral difficulties and the self-esteem of gifted children.

\section{Literature Review}

Blaas (2014) stated that gifted children are a specific minority with high scores of intelligence and their needs are often not identified in the typical classroom. Abdel-Khalek, Korayem, \& El-Nayal, (2012) found that children with high self-esteem experienced more joy, hopefulness and motivation and less sadness and anxiety and had positive peer relationships. Similar ideas presented by Kostogianni and Andronikof (2014) who noted that a high degree of self-esteem enabled children with high self-esteem to enjoy good times, handle bad situations, face obstacles efficiently, minimize behavioral, emotional and peer problems and increase their power.

Noorsyakina et., al. (2020) in an empirical study done with gifted children in Malaysia with 112 samples (47 males and 65 females) measured levels of depression, physical and behavioral difficulty among gifted students. The results showed that gifted students presented levels of depression and physical difficulties, as well as low levels of behavioral difficulties. Mueller and Winsor (2018) stated that gifted adolescents had a high prevalence of psychological and social problems, especially those surrounding behavior based on school issues. Orth and Robins (2013) mentioned similar ideas that gifted children with poor self-esteem presented negative emotions, social issues, feelings of inferiority and psychological instability and these contributed to unhappiness in life. Maksic, (1998) research study was to see how gifted students in ordinary classrooms were accepted by their peers. The results revealed that the adolescence gifted students were more readily accepted in academic endeavors than in other areas of peer acceptability. Govier (1993) study proved that gifted students presented higher levels of social skills and low scores of antisocial behavior. But same study found that small subset of gifted children presented poor social skills and higher levels of behavioral problems. Fabian, et., al. (2013) research found that gifted children with IQ $\geq 130$ displayed increased behavioral problems in the whole symptomatic range. "Highly gifted" children did not display more behavioral problems than the "low gifted." Vialle, Heaven, and Ciarrochi (2007) studies have shown that gifted students had significantly higher academic outcomes for all subject areas except two. Teachers reported that gifted students are well-adjusted to the classroom and presented less behavioral problems. But same research proved that gifted children are encountered with feeling sad, less satisfied their social support when compared to the non-gifted children.

Gross (2006); Neihart (1999) research studies proved that the highly gifted students are more likely to feel socially isolated. Studies by Cynthia, Gerald, Carol, Richard, (1996) highlighted that gifted and average IQ students do not differ in quality of and satisfaction with peers' relations. Researchers proved that gifted children growing up to adolescence, decrease their peer relations. Reviewing the empirical studies it can be concluded that the negative psychological impact of classroom factors influence gifted children. 


\section{METHODS AND MATERIAL}

\section{Sample}

The sample survey research design and a snowballing sample method were employed to identify 102 gifted children in Junior Secondary classes (40 males and 62 females), from five districts (Colombo, Kalutara, Gampaha, Ratnapura and Kegalle) in the Western and Sabaragamuwa Provinces of Sri Lanka. Gifted children were selected by teacher nominations and Raven's Standard Matrix IQ test. According to the Raven test, students with a chronological age of 12-14 who scored above 95 percentile points (over 51-53 level) in the IQ test were identified as gifted. Accordingly, 40 boys and 62 girls were selected from the two provinces.

\section{Instruments}

Two standardized tests were used for this study: Raven's Progressive Matrices Intelligence Quotient (IQ) test and Cooper Smith's (2002) Self-Esteem Inventory. Raven's Progressive Matrices Intelligence Quotient (IQ) test was non-verbal, comprising of 60 multiple choice questions becoming progressively more difficult. For each test item, the subject was asked to identify the missing element that completed a pattern. Many patterns were presented in the form of a $6 \times 6,4 \times 4,3 \times 3$ or $2 \times 2$ matrix. The test reliability was $(\alpha=0.71)$.

Coopersmith's (2002) Self-Esteem Inventory was used to measure the level of self-esteem of the gifted children. The scale consisted of 58 self-reported items. Each item was answered on a two-point scale 'like me' (1) and 'unlike me' (0). Reliability and validity for this study was $(\alpha=0.73)$. The factors and psychological difficulties influencing students in the classroom were measured using a self-developed questionnaire. This questionnaire included emotional, physical and behavioral difficulties and the nature of peer relationships. Each sub-theme consisted of question statements answered by ticking a five-point Likert scale: 'never-always'. The reliability of the questionnaire was $(\alpha=0.67)$. Structured interviews were also conducted with the students, to identify social difficulties such as peer pressure, isolation, neglect by the teachers etc. Informed consent was obtained from the participants and permission was obtained from the school authorities as part of the study process. Ethical clearance was approved by the faculty research committee of the Faculty of Education.

The methods used for data analysis were mainly quantitative data analysis techniques such as average mean and standard deviation, Chi-square and percentages.

\section{RESULTS AND DISCUSSION}

The total number of respondents who participated in this survey was 102 . Sixty one percent $(61 \%-62)$ were female and 39\% (40) were male. The classroom factors that influenced gifted children such as issues related to the teaching-learning process, were identified as trigger factors, as shown in Table 1.

Table 1. Teaching-Learning process with Gifted Children

\begin{tabular}{lll} 
Teaching -Learning Process & Mean & SD \\
\hline $\begin{array}{l}\text { Teachers' lack of attention to the unique } \\
\text { development of gifted children }\end{array}$ & & 1.04
\end{tabular}

\begin{tabular}{llc}
\hline Teachers' neglect & 3.85 & 1.03 \\
\hline Fewer opportunities provided for gifted & 3.29 & 1.05 \\
children in the classroom & & \\
& & \\
\hline The evaluation system is not focused on & 3.73 & 1.22 \\
academic success & & \\
& & \\
\hline The relevant teaching-learning methods & 2.97 & \\
were not used for specific gifted children & & \\
& & \\
\hline Class-teachers lack the required skills to & 4.11 & \\
teach gifted children & & \\
\end{tabular}

The item 'Teachers' lack of attention to the unique development of gifted children' was $(\mathrm{M}=4.04, \mathrm{SD}=$ 1.04). 'Class-teachers lack the required skills to teach 
gifted children' $(\mathrm{M}=4.11, \mathrm{SD}=0.98)$ presented as a prominent factor that negatively affected the students. The item 'Teachers' neglect' was ( $\mathrm{M}=3.85, \mathrm{SD}=1.03)$. The item 'Fewer opportunities provided for gifted children in the classroom' was $(\mathrm{SD}=3.29, \mathrm{SD}=1.05)$.
The item 'The evaluation system is not focused on academic success' was $(\mathrm{M}=3.73, \mathrm{SD}=1.22)$. The relevant teaching-learning methods were not used for specific gifted children' $(\mathrm{M}=2.97, \mathrm{SD}=1.61)$.

Table 2 : Gifted Children's Emotional Difficulties

\begin{tabular}{|l|l|l|l|l|l|l|l|}
\hline $\begin{array}{l}\text { Emotional Difficulties } \\
\text { Items }\end{array}$ & $\begin{array}{l}\text { Never } \\
(\%)\end{array}$ & $\begin{array}{l}\text { Seldom } \\
(\%)\end{array}$ & $\begin{array}{l}\text { Sometimes } \\
(\%)\end{array}$ & $\begin{array}{l}\text { Often } \\
(\%)\end{array}$ & $\begin{array}{l}\text { Always } \\
(\%)\end{array}$ & $\begin{array}{l}\text { Chi- } \\
\text { Square } \\
\chi 2\end{array}$ & $\begin{array}{l}\text { P- } \\
\text { value }\end{array}$ \\
\hline I felt unhappy & 2 & 10.8 & 17.6 & 39.2 & 30.4 & 61.039 & .000 \\
\hline $\begin{array}{l}\text { I felt my feeling are not so } \\
\text { good anymore }\end{array}$ & 2.9 & 15.7 & 24.5 & 31.4 & 25.5 & 24.961 & .000 \\
\hline I hated myself & 0 & 18.6 & 40.2 & 27.5 & 13.7 & 16.510 & .001 \\
\hline $\begin{array}{l}\text { When I feel lonely, I feel } \\
\text { like no one loves me }\end{array}$ & 5.9 & 15.7 & 24.5 & 36.3 & 17.6 & 27.314 & .000 \\
\hline I get angry easily & 5.9 & 16.7 & 20.6 & 27.5 & 29.4 & 25.941 & .000 \\
\hline
\end{tabular}

With regard to the emotional difficulties of gifted children in the classroom: five items in the questionnaire were related to the nature of their emotional difficulties in the typical classroom. The findings indicated that gifted children had significant emotional difficulties (Table 2). Only two per cent of the children replied 'Never' to the statement: 'I felt unhappy'. $10.8 \%$ of the children responded 'Seldom' and $17.6 \%$ responded 'Sometimes', while 39.2\% responded 'Often and $30.4 \%$ responded 'Always' to the same question. This is generalized to the gifted children population and proved by the Chi-square test $(\chi 2=61.039, \mathrm{p}=.000)$.

Twenty-four point five per cent (24.5\%) of the children responded 'Sometimes' to the statement ' $I$ felt my feeling are not so good anymore'. Thirty-one point four per cent (31.4\%) responded 'Often' while $25.5 \%$ responded 'Always' to the same question.
Fifteen point seven per cent (15.7\%) responded 'Seldom' and 2.9\% responded 'Never'. The results can be generalized to the population $(\chi 2=24.961, \mathrm{p}$ $=.000$ ). To the statement 'I hated myself', $40.2 \%$ responded 'Sometimes' and $27.5 \%$ chose 'Often' while $13.7 \%$ responded 'Always'; a clear indication that gifted children had significant emotional difficulties in a typical classroom environment $(\chi 2=16.510, \mathrm{p}$ $=.001)$. Only five point nine per cent $(5.9 \%)$ of the children responded 'Never' to the statement: 'When $I$ feel lonely, I feel like no one loves me'. 15.7\% responded 'Seldom' and $24.5 \%$ responded 'Sometimes' while $36.3 \%$ responded 'Often' and $17.6 \%$ responded 'Always'. These were significantly high scores $(\chi 2=$ $7.314, \mathrm{p}=.000)$.

Sixteen point seven per cent $(16.7 \%)$ of the gifted children responded 'Seldom' to the emotional statement 'I get angry easily', while 20.6\% responded 'Sometimes', 27.5\% responded 'Often' and only $29.4 \%$ 
responded 'Always', although 5.9\% responded 'Never' to the same question. The emotional difficulties of gifted children with regards to 'getting angry easily' presented significant scores $(\chi 2=25.941, \mathrm{p}=.000)$. These findings are in line with previous studies done by Orth and Robins (2013); Kourkouta, Ilitadis, and Monios, (2015); Fallon, Danielle, and Emina, (2020); Lee, Olszewski, Makel and Putallaz (2015).

Table 3 : Gifted Children's Physical and Behavioral Difficulties

\begin{tabular}{|l|l|l|l|l|l|l|l|}
\hline $\begin{array}{l}\text { Physical and Behavioral } \\
\text { Difficulties }\end{array}$ & $\begin{array}{l}\text { Never } \\
\%\end{array}$ & $\begin{array}{l}\text { Seldom } \\
\%\end{array}$ & $\begin{array}{l}\text { Sometimes } \\
\%\end{array}$ & $\begin{array}{l}\text { Often } \\
\%\end{array}$ & $\begin{array}{l}\text { Always } \\
\%\end{array}$ & $\begin{array}{l}\text { Chi- } \\
\text { square } \\
\chi 2\end{array}$ & P value \\
\hline I feel so tired & 1 & 27.5 & 37.3 & 16.7 & 17.6 & 37.314 & .000 \\
\hline I get headaches easily & 11.8 & 16.7 & 27.5 & 24.5 & 19.6 & 7.902 & .092 \\
\hline I have sleeping difficulties & 7.8 & 12.7 & 23.5 & 27.5 & 28.4 & 17.314 & .002 \\
\hline $\begin{array}{l}\text { I sit and do nothing in the } \\
\text { classroom }\end{array}$ & 1 & 29.4 & 35.3 & 13.7 & 20.6 & 36.992 & .000 \\
\hline I can't manage things & 5.9 & 10.8 & 16.7 & 24.5 & 42.2 & 26.137 & .000 \\
\hline I do everything wrong & 2 & 24.5 & 29.4 & 30.4 & 13.7 & 29.667 & .000 \\
\hline $\begin{array}{l}\text { I do not reach the goal that I } \\
\text { have planned }\end{array}$ & 3.9 & 13.0 & 26.5 & 36.3 & 19.6 & 30.843 & .000 \\
\hline
\end{tabular}

As shown in Table 3, with regards to the statement about gifted children's physical difficulties: 'I feel so tired', thirty-seven point three per cent (37.3\%) responded 'Sometimes', 27.5\% responded 'Seldom' while $16.7 \%$ responded 'Often' and $17.6 \%$ responded 'Always', although $1 \%$ of the sample children responded 'Never'. The generalized Chi-square results relating to the statement 'I feel so tired' showed that gifted children have physical difficulties including 'feeling tired' ( $\chi 2=37.314, \mathrm{p}=.000)$.

To the statement 'I get headaches easily', twentyseven point five per cent (27.5\%) responded 'Sometimes', 24.5\% responded 'Often' and 19.6\% responded 'Always'. 11.8\% responded 'Never' and $16.7 \%$ responded 'Seldom' to the same question. However the gifted children did not significantly present 'getting headaches easily due to classroom environment influences' ( $\chi 2=7.90 \mathrm{p}=.092$ ). To the statement 'I have sleeping difficulties', $28.4 \%$ responded 'Always', 27.5\% responded 'Often' and 23.5\% responded 'Sometimes'. 7.8\% responded
'Never' and $12.7 \%$ responded 'Seldom' to the same question.

In general, gifted children presented with significant 'sleeping difficulties due to classroom factors' ( $\chi 2=$ 17.314, $\mathrm{p}=.002$ ). As shown in Table 3 , regarding the statement 'I sit and do nothing in the classroom', $35.3 \%$ responded 'Sometimes', 20.6\% responded 'Always' and $13.7 \%$ responded 'Often', although 29.4\% responded 'Seldom' to the same question. When generalizing this statement, the Chi-square results showed significant scores of gifted children who 'sit and do nothing in the classroom' $(\chi 2=36.992$, $\mathrm{p}=.000)$. Regarding the statement 'I do everything wrong', 30.4\% responded 'Often' and 29.4\% responded 'Sometimes', while 24.5\% responded 'Seldom'. Gifted children significantly presented ' $I$ do everything wrong' $(\chi 2=26.997$, $\mathrm{p}$ $=.000)$. Relating to the statement 'I do not reach the goal that I have planned', the results were $(\chi 2=$ 30.843, $\mathrm{p}=.000)$. These findings are in line with previous studies done by Gover, (1993); Fabian, et, al. (2013); Noorsyakina, et., al. (2020). 
Table 4: Nature of Peer Relationships

\begin{tabular}{|c|c|c|c|c|c|c|c|}
\hline Nature of Peer Relationships & $\begin{array}{l}\text { Never } \\
(\%)\end{array}$ & $\begin{array}{l}\text { Seldom( } \\
\%)\end{array}$ & $\begin{array}{l}\text { Sometim } \\
\text { es (\%) }\end{array}$ & $\begin{array}{l}\text { Often } \\
(\%)\end{array}$ & $\begin{array}{l}\text { Always( } \\
\%)\end{array}$ & $\begin{array}{l}\text { Chi- } \\
\text { Square } \\
\chi 2\end{array}$ & $\begin{array}{l}\mathrm{P} \\
\text { value }\end{array}$ \\
\hline $\begin{array}{l}\text { When I am with my friends, I } \\
\text { avoid peers who do not } \\
\text { belong to my group }\end{array}$ & 9.8 & 10.8 & 15.7 & 30.4 & 33.3 & 25.157 & .000 \\
\hline $\begin{array}{l}\text { I compare my abilities with } \\
\text { my peers }\end{array}$ & 6.9 & 5.9 & 18.6 & 34.3 & 34.3 & 39.961 & .000 \\
\hline $\begin{array}{l}\text { It is more important to me to } \\
\text { do what my peers expect me } \\
\text { to do than to satisfy my } \\
\text { desires }\end{array}$ & 2 & 11.8 & 26.5 & 33.3 & 26.5 & 33.393 & .000 \\
\hline $\begin{array}{l}\text { I behave in a way that does } \\
\text { not suit me, to fit in with the } \\
\text { group }\end{array}$ & 1 & 11.8 & 15.7 & 40.2 & 31.4 & 50.255 & .000 \\
\hline
\end{tabular}

the statement 'I behave in a way that does not suit me,

According to Table 4, the majority of the gifted children indicated that they had no proper peer relations with their peers in the classroom. To the statement 'When I am with my friends, I avoid peers who do not belong to my group', 30.4\% responded 'Often' and $33.3 \%$ responded 'Always'. The Chisquare test results proved significant $(\chi 2=25.157$, the $\mathrm{p}=.000)$. The Chi-square test also showed that the gifted children compared themselves with their peers with regard to their abilities $(\chi 2=39.961, \mathrm{p}=.000)$. To the statement 'It is more important to me to do what my peers expect me to do than to satisfy my desires', thirty-three point three per cent (33.3\%) responded 'Often' and 26.5\% replied 'Always'.

The gifted children in the sample significantly showed that their peers do not consider gifted children's desires $(\chi 2=33.393, \mathrm{p}=.000)$. Regarding to fit in with the group', the children presented ( $\chi 2=$ $50.255, \mathrm{p}=.000)$. These findings are in line with previous studies done by Neihart (1999); Gross (2004); Cynthia, Gerald, Carol, and Richard, (1996) ; Mueller and Winsor (2018); Maksic (1998); Vialle, Heaven, and Ciarrochi (2007).

The relationship between self-esteem and psychological difficulties in gifted children

According to the self-esteem test, the average score obtained for the level of self-esteem is given in the Table 5. as below. The scores are segregated by gender. The average levels of self-esteem for males and females were 40 and 39, respectively. Very low selfesteem scores were shown for the males (33) and for the females (32). On the other hand, the male scores of 47 and the female scores of 46 were regarded as very high levels of self-esteem. 
Table 5 : Distribution of the Average Level of Self-esteem of Gifted Children

\begin{tabular}{|c|c|c|c|c|c|c|c|c|c|c|}
\hline \multirow[t]{2}{*}{ Level of self-esteem } & \multicolumn{2}{|c|}{ Very Low } & \multicolumn{2}{|c|}{ Low } & \multicolumn{2}{|c|}{ Average } & \multicolumn{2}{|c|}{ High } & \multicolumn{2}{|c|}{ Very High } \\
\hline & $\mathrm{M}$ & $\mathrm{F}$ & $\mathrm{M}$ & $\mathrm{F}$ & $\mathrm{M}$ & $\mathrm{F}$ & M & $\mathrm{F}$ & $\mathrm{M}$ & $\mathrm{F}$ \\
\hline Gifted children (Frequency) & 12 & 18 & 11 & 6 & 4 & 8 & 3 & 10 & 11 & 19 \\
\hline Self-esteem average scores & 33 & 32 & 36 & 35 & 40 & 39 & 44 & 43 & 47 & 46 \\
\hline
\end{tabular}

According to Table 5, twelve male and eighteen female gifted children had scores for a very low level of self-esteem (33-32). Both groups of children had scores for a low level of self-esteem (36-35) and both male and female-altogether 12 children-presented an average level of self-esteem (40-39). Thirteen children in the sample had high scores (44-43) and thirty children-11 male and 19 female-presented very high scores for levels of self-esteem (47-46). The overall low scores for self-esteem were presented by forty-seven children in comparison to the average and higher scores. Self-esteem low scores results are in line with previous studies done by Pilarinos and Solomon (2017); Kroesbergen et., al. (2016); Crone and Dahl (2012). The correlation results showed a significant relationship between the psychological difficulties and self-esteem of the gifted children. There is also a significant relationship between their emotional difficulties and self-esteem $(\mathrm{r}=.378, \mathrm{p}$ $=.001)$, physical difficulties and self-esteem presented a significant relationship $(\mathrm{r}=0.326, \mathrm{p}=.029)$ and behavioral difficulties stated $(\mathrm{r}=.468, \mathrm{p}=.000)$ significantly.

\section{v. CONCLUSION}

Gifted children in the typical classroom environment encountered psychological issues leading to various emotional, behavioral and physical difficulties and problems with peer relations. Classroom factors influencing gifted children included teachers' neglect, fewer opportunities for gifted children in the classroom, a lack of proper methods of evaluation and a lack of relevance in the teaching-learning process. These factors negatively affected gifted children in the classroom. Consequently, these children encountered various emotional, physical and behavioral problems and difficulties with peer relationships.

The majority of the children in the sample presented with low self-esteem. There is a significant positive correlation between emotional and behavioral problems and peer pressure difficulties and selfesteem, except for physical difficulties. Thus, it seems vital that teachers should develop professional skills and receive more teacher training related to special education within inclusive classrooms. It is also important to provide integrated professional counselling services in order to increase the selfesteem and psychological well-being of these talented children, in the school system.

\section{REFERENCES}

[1]. Abdel-Khalek, A. M., Korayem, A. and ElNayal. M. (2012). Self-esteem among college 
students from four Arab countries. Psychological Reports, 110, 297-303.

[2]. Blaas, S. (2014). The Relationship between Social-Emotional Difficulties and Underachievement of Gifted Students, Australian Journal of Guidance and Counselling, Vol. 24, p. $243-255$.

[3]. Coopersmith, S . (2002). Coopersmith SEI selfesteem inventories manual. Menlo Park: CA: Mind Garden, Inc.

[4]. Crone, E., and Dahl, R. (2012). Understanding adolescence as a period of social-affective Engagement and goal flexibility. Nat Rev Neurosci, 13, pp. 636-650. https://doi.org/10.1038/nrn3313.

[5]. Cynthia, G. S., Gerald, C., M. Carol, M., E., and Richard D. (1996). Student Self- Esteem and the School System: Perceptions and Implications, The Journal of Educational Research, 89:5, 286293, DOI: 10.1080/00220671.1996.9941330

[6]. Fabian, G., Jacqueline, L., Christian, C., JeanMarc, B., Claire, M., Pierre, F., and Oliver, R. (2013) Behavioral Profiles of Clinically Referred Children with Intellectual Giftedness, BioMed Research International Vol ID540153, https://doi.otg/10.1155/2013/54015.

[7]. Fallon, C., Danielle, H., and Emina., O. (2020). The sleep and mental health of gifted children: A prospective, longitudinal, community cohort study, Gifted and Talented International, 35:1, 16-26. DOI: 10.1080/15332276.2020.1758977

[8]. Govier, T., R., U., D., Y. (1993). Self-Trust, Autonomy, and Self-Esteem. Hypatia, 8(1), 99$120 . \quad$ https://doi.org/10.1111/J.15272001.1993.TB00630.X

[9]. Gross, M., U., M. (2006). Exceptionally Gifted Children: Long-Term Outcomes of Academic Acceleration and Nonacceleration. Journal for the Education of the Gifted, 29(4):404-429. doi:10.4219/jeg-2006-247

[10]. Kostogianni, N., and Andronikof, A. (2014).Self-esteem and giftedness: a Rorschach
Comprehensive System study. Journal of Encephale. 40 (1), P. 3-8. French. doi: 10.1016/j.encep.2013.01.001. Epub 2013 Mar 29. PMID: 23545477.

[11]. Kourkouta, L., Ilitadis, C., H., and Monios, A. (2015). Psychosocial issues in elderly, Progress in Health Sciences, Volume 5, p. 232-237.

[12]. Kroesbergen, E. H., van Hooijdonk, M., Van Viersen, S., Middel-Lalleman, M., M., N., and Reijnders, J., J., W. (2016). The psychological well-being of early identified gifted children. Gifted Child Quarterly, Volume 60, p. 16-30. Doi: 10.1177/0016986215609113

[13]. Lee, S., Y., Olszewski, K., P., Makel, M., C., and Putallaz, M. (2015). Gifted Students' Perceptions of an Accelerated Summer Program and Social Support. Gifted Child Quarterly. 59 (4) p. 265-282. Doi:10.1177/0016986215599205

[14]. Maksic, S. (1998) Peers Relations of Gifted Students. In Congresso International de Sobredotacao: Problematica Socio-Educativa ACTAS, Americana, ISMAI, 13/16 Outubra 1996, Porto, Portugal (pp. 435-455). Porto: APEPICT.

[15]. Mueller, C. E., and Winsor, D. L. (2018). Depression, suicide, and giftedness: Disentangling risk factors, protective factors, and implications for optimal growth. In S. I. Pfeiffer (Ed.), Handbook of giftedness in children, (pp. 255-284). Cham, Switzerland: Springer.

[16]. Mustika, I., W., and Harini, G., A. (2017). Increasing Education of Family Support for Decreasing Depression Level towards Elderly. International Journal of Health Sciences (IJHS), 1(3), 10-16.

[17]. Neihart, M. (1999) The impact of giftedness on psychological well-being: What does the Empirical literature say?, Roeper Review. 22(1):10-17.DO - 10.1080/02783199909553991

[18]. Noorsyakina, S., Che Zarrina, S., Sharifah, B., S., M., Nurul, S., J., and Mohd, H., Z., A. (2020). 
Depression anxiety cognitive difficulties among gifted and talented students in Malaysia during the movement control order (MCO). Journal of Critical Reviews, 743-745.

[19]. Orth, U., and Robins, R., W. (2013). Understanding the link between low selfesteem. Current Directions in Psychological Science, 22, 455-460.

[20]. Pilarinos, V., and Solomon C.,R. (2017) Parenting Styles and Adjustment in Gifted Children. Gifted Child Quarterly. 61(1):87-98. doi:10.1177/0016986216675351

[21]. Raven, J., C. Court, J.,H., and Raven., J. (1995). Manual for Raven's Progressive Matrices and Vocabulary Scales. Oxford: Oxford Psychologist Press.

[22]. Vialle, W., Heaven, P., C., L., and Ciarrochi, J. (2007). On being gifted, but sad and misunderstood: Social, emotional, and academic outcomes of gifted students in the Wollongong Youth Study. Educational Research and Evaluation, 13(6), 569-586. https://doi.org/10.1080/13803610701786046

\section{Cite this article as :}

Kamani Priyadarshani, Samudra Senarath, "Classroom Factors that Influence Self-esteem in Gifted Children : A Case Study in Sri Lanka", International Journal of Scientific Research in Science and Technology (IJSRST), Online ISSN : 2395-602X, Print ISSN : 23956011, Volume 8 Issue 5, pp. 242-251, SeptemberOctober 2021. Available at doi : https://doi.org/10.32628/IJSRST218537

Journal URL : https://ijsrst.com/IJSRST218537 